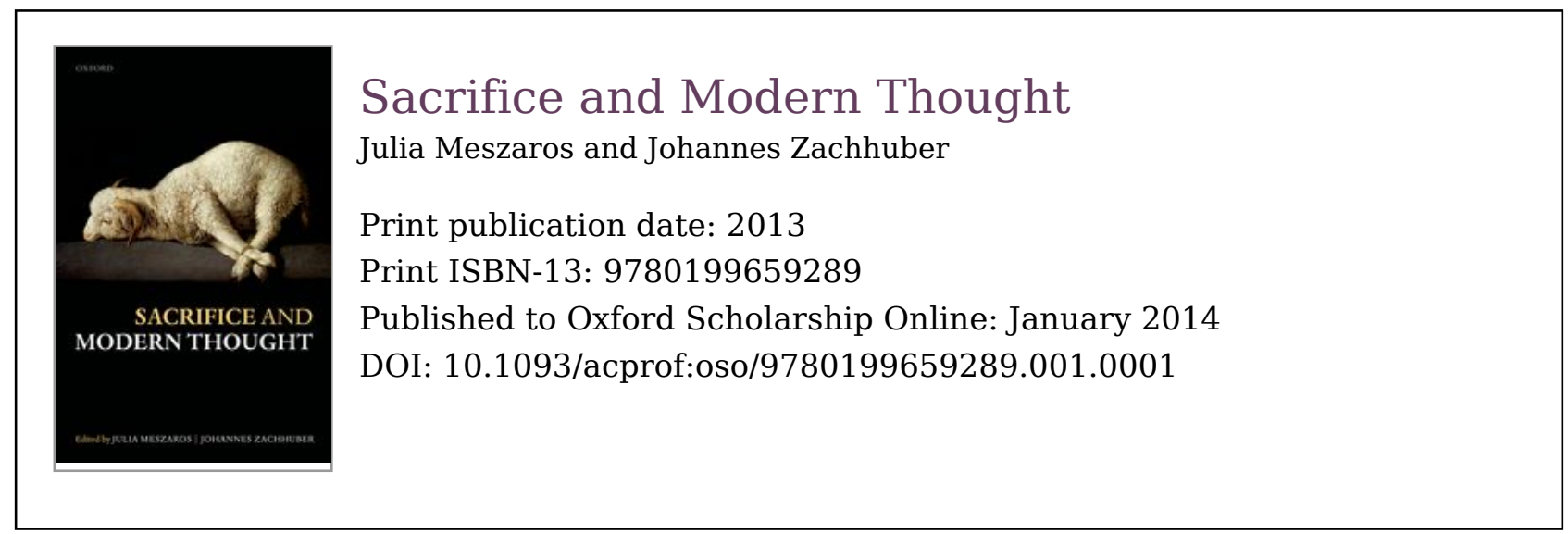

\title{
Modern Discourse on Sacrifice and its Theological Background
}

Johannes Zachhuber

DOI:10.1093/acprof:oso/9780199659289.003.0002

\begin{abstract}
Keywords
The chapter shows how contemporary secular debates about sacrifice still draw on Christian theological ideas. It identifies two main strands in contemporary perceptions of sacrifice: on the one hand, sacrifice is understood in terms of victimization (Girard), on the other, modern individualism is seen as standing in the way of sacrificial actions for the good of the community (Durkheim). Both ideas can be explained on the basis of characteristic transformations the notion of sacrifice underwent in the context of Christianity, which originates after the end of ritual sacrifice but which, with the notion of Christ's atoning death, nonetheless gives the most central place imaginable to the idea of sacrifice. Christ's death comes to signify both the symbol of the selfless gift of one's life for one's friends and the suffering of the innocent victim. Both ideas today survive in secularized form and continue to exert potent influence in our culture.
\end{abstract}

Keywords: victimization, individualism, Girard, Durkheim, atonement, secularization

Most contemporary discussions about sacrifice are not theological in character. Yet the absence of overtly theological arguments from these debates does not mean that the specific concerns of Christian theology are equally absent from them. It is my aim in this chapter to illustrate how modern, secular discourse about sacrifice still draws on theological ideas and, in fact, needs this background to be properly understood. It is, perhaps, needless to say that by arguing this case I do not intend to deny the presence of various other sources of influence on contemporary ideas of sacrifice; nor does my argument per se 
serve to disown the legitimacy of modern, secular concern for this cultural practice. Historical lineage, after all, cannot easily tell us whether what we think or do is right or wrong; it does, however, help us better understand it: in this sense, my argument in this chapter is meant to be hermeneutical.

My second caveat must be that by focusing on the trajectory from theological to non-theological thought about sacrifice, I do not wish to imply that meaningful reflection about sacrifice within Christian theology has come to an end. This would obviously be false, and several contributions to the present book demonstrate the vitality of this discourse and its ongoing significance. My interest in this chapter, however, is not in self-consciously theological reflection about sacrifice; it is in those contemporary references to 'sacrifice' we might wish to call a 'survival' (to use Tylor's celebrated phrase) of religious language in contexts that today are no longer governed by theological principles. While some of those may have become entirely devoid of deeper meaning, I would contend that this is not universally the case: the rhetorical urgency that is usually attached to the mention of sacrifice at least suggests otherwise.

How can we describe this secular or quasi-secular usage? Following Ivan Strenski, ${ }^{1}$ I would suggest that two somewhat conflicting ideas are central: on (p.13) the one hand, there is a critical view for which sacrifice is associated with violence and, therefore, cruelty. Sacrifice is the wasteful loss of human life for a supposed gain in some public good. This negative evaluation of sacrifice may refer to the willingness of a political or military leader to 'sacrifice' others in the interest of a larger project. It may, however, also denote self-sacrifice especially where the latter appears as a misguided subjection of the individual to the demands of social or cultural norms; as we have become more familiar with the potential of self-harm inflicted to itself by an individual under the influence of collectively shared ideologies, our suspicion towards altruistic, sacrificial acts has increased.

The other strand in contemporary references to sacrifice is focused more on the potential loss of communal cohesion that is indicated by the receding willingness of individuals to give up something precious to them for the good of the group. Sacrifice is encouraged or even demanded as a symbol of people's commitment to their class or nation, as a token for the person's awareness of the value they gain from their integration into a functioning social whole. Such affirmation of sacrifice is predicated on the perception that modernity has brought about a slackening of social cohesion often expressed through the term 'individualism' gesturing at the spectre of a society consisting of intrinsically selfish individuals held together only by the fragile bond of their calculated self-interest.

Both views are not detached from theoretical and academic debates: the link between sacrifice and violence has been emphasized in pivotal contributions by René Girard and Walter Burkert. In different ways, both connect the historical 
origins of the ritual with the need for early human society to cope with aggression and the spilling of blood. For Burkert, sacrifice arose specifically as a response to the regular killing of animals by palaeolithic hunter cultures ${ }^{2}$ whereas Girard, as several other contributors to this volume explain in more detail, perceives it as the ritual re-enactment of an original expulsion of a scapegoat by means of which community cohesion was only established. ${ }^{3}$ More important, however, than their problematic constructions of historical or prehistorical origins is that their perception of the sacrificial act is firmly victimoriented; what is done to the victima, its immolation, determines the interpretation of sacrifice as such.

By contrast, the alternative, popular view, according to which willingness to sacrifice correlates with the integration of the individual into a larger social whole, considers sacrifice from the point of view of the person bringing the sacrifice, the sacrifier as Hubert and Mauss call them. ${ }^{4}$ What are the reasons that motivate or indeed demotivate an individual to give up something for a (p. 14) 'transcendent' good? Here the influence of Émile Durkheim and his school has loomed large: from his early work on suicide, the French sociologist saw anomy as the great threat to a society whose members were no longer properly integrated. His later theory of religion was inscribed into that same diagnosis: religion is community cohesion and secularization, consequently, a lessening of those cohesive forces, which can potentially have detrimental consequences for the very existence of modern societies.

The two ways in which contemporary discourse mostly refers to sacrifice, then, correspond to specific conceptions, if not theories, of sacrifice. This is not trivial; sacrifice as has often been noted is a polyvalent term and the ritual it originally denoted, a complex sequence of acts with various participants. How one thinks or speaks about it therefore at least partly depends on one's perception, on what one sees when envisioning a sacrifice. The views that were briefly sketched differ in that one emphasized the passive suffering of the offering, whereas the other fastens on the psychology and the moral attitude of the 'sacrifier'.

Both, however, are the result of specific transformations of the concept of sacrifice in Christian theology. They derive, or so I shall argue, from the deeply ambiguous, even precarious position sacrifice has held in the theory and practice of Christianity from the very beginning: sacrifice was part of a dispensation that had come to its end but at the same time continued to hold sway over theological and spiritual reflection with unique intensity due to the way the 'end of the law' (Rom. 10:4) was identified with the Christ event. I shall proceed, therefore, from a brief historical sketch of the origins of Christian reflections about sacrifice to move on directly to their substantial transformation in early modernity. The latter results, as I shall show, in the imperative of dutiful 
sacrifice as service for the common good on the one hand, its critical rejection as senseless violence against innocents on the other.

1. The origins of Christianity and the 'end of sacrifice'

The End of Sacrifice is the title Guy Stroumsa has given to his landmark study into the transformation of religion in late antiquity. ${ }^{5}$ The term of course, as Stroumsa himself recognizes, is hyperbolic: sacrifice did not end in late antiquity; in fact, the religions originating during this period, rabbinic Judaism, Christianity, and Islam all develop their own complex, but ambivalent attitude to sacrifice which combines critique with reinterpretation and transformation. (p.

15) Yet Stroumsa is surely right to see the decline of ritual sacrifice along with the emergence of monotheism, a stronger emphasis on the self, the codification of religious norms in revealed books, and the detachment of religion from any particular political entity as symptoms of a fundamental paradigm shift in religion occurring during the first millennium.

It is this world into which Christianity evolves, and within the broader parameters of its culture, the Christian religion unmistakably is aligned with the forces of modernization. Emperor Julian the 'Apostate', a romantic conservative who in the mid-fourth century made a last-ditch attempt to restore the old order, lays this charge at the feet of the 'Galileans': ${ }^{6}$

Why do you not sacrifice [...]? [...] The Jews agree with the Gentiles, except that they believe in only one God. That is indeed peculiar to them and strange to us; since all the rest we have in a manner in common with them -temples, sanctuaries, altars, purifications, and certain precepts. For as to these we differ from one another either not at all or in trivial matters. ${ }^{7}$

Elsewhere in his treatise, the emperor permits the Christians to reply with the argument that 'on our behalf Christ was sacrificed once and for all.' 8 This is indeed perhaps the most intuitive answer a theologian may be inclined to give to the question why Christians from the very beginning did not practice traditional forms of sacrifice: for them, the death of Christ was the perfect and therefore last sacrifice. Yet while this argument is occasionally adduced by early Christian authors, ${ }^{9}$ it does not, on the whole, dominate Christian attitudes to sacrifice in late antiquity.

Throughout the New Testament, evidence for a critical rejection of Jewish sacrifice is scarce. Paul calls Jesus Christ 'our paschal lamb' (1 Cor. 5:7); he does not say that the slaughtering of lambs at Passover is wrong. Jewish ritual sacrifice, however, was confined to the temple in Jerusalem and thus no longer part of everyday worship for the vast majority of Jews living around the Mediterranean. It was altogether discontinued after the temple's destruction in 70ADeven though its principal significance continued to be affirmed by the Rabbis. One of Emperor Julian's more fanciful projects therefore was the rebuilding of the temple: in his calculation, Jewish sacrifice would then resume 
and Christians would be exposed as the one religious group without a proper sacrifice. ${ }^{10}$ The plan never came to fruition but points to the partly contingent character of the abolition of ritual blood sacrifice in Judaism.

An analogous plan, obviously, could not have been offered to the Christians, but historical evidence suggests that nevertheless early Christian responses (p.16) to sacrifice mirrored closely the pragmatic strategies adopted in Hellenistic Judaism to cope with the absence of ritual sacrifice: its reinterpretation as primarily an internal act of devotion to God and the endowment of originally non-sacrificial rituals, such as prayers and meals, with a quasi-sacrificial character. Thus, beginning from the late first or the early second century, the Lord's Supper is referred to as 'sacrifice' (thusia ). Its supersession of the Jewish sacrifice is justified with Mal. 1:11: 'In every place incense is offered in my name, and a pure offering'. ${ }^{11}$ The verse had already been popular in Hellenistic Judaism, as we know from Justin Martyr (c.150): ${ }^{12}$ it was applied to the prayers of the individuals' in the diaspora as being superior to the temple cult in Jerusalem. While the apologist insists that the prophetic word is fulfilled only in the Christian Eucharist, he explicitly agrees with his Jewish interlocutor that 'prayers and giving of thanks, when offered by worthy men, are the only perfect and well-pleasing sacrifices to God' ${ }^{13}$ Both strategies, then, are seen here in combination: sacrifice is fundamentally redefined as an internal and ethical disposition of the believer. The Eucharist, as its very name suggests, was considered in this sense a 'sacrifice of prayer and thanksgiving', while as a ritual it has direct parallels with Jewish morning prayers that were developed in the diaspora as substitutes for the temple cult. ${ }^{14}$

This approach reaches its apogee in Augustine's discussion of sacrifice in book ten of The City of God, the most extensive Patristic treatment of sacrifice, which in many ways was to become the classical point of reference for later theologians. ${ }^{15}$ According to the Bishop of Hippo, sacrifice is every work that establishes community between human beings and God. It can, but does not have to, be ritual: Old Testament sacrifices, therefore, were justified as symbols of the interior act of orienting the person towards their creator. They had to be abolished at some point so that no one would confuse the outward activities with their real, spiritual meaning, which for Augustine comprises attitudes such as contrition (cf. Ps. 51:16-17), glorification (Ps. 50:14-15), as well as moral behaviour ('do justly, love mercy, walk humbly with God', cf. Mic. 6:8). In sum: 'all the divine ordinances [...], which we read concerning the sacrifices in the service of the tabernacle or the temple, we are to refer to the love of God and our neighbour'. ${ }^{16}$

(p.17) Augustine's argument distinctly betrays its late ancient context.

Christians were faced with the lingering reality of pagan sacrifices, which they rejected, but also with the literary heritage of the sacrificial cult ordained in the Mosaic law, which they defended as a divine institution while at the same time 
justifying its discontinuation in Christianity. The most promising response to this challenge seemed to consist in a symbolic theory which relocated the essence of sacrifice from a sequence of acts to their underlying intellectual and volitional motivation: 'That which in common speech is called sacrifice is only the symbol of the true sacrifice' (illud, quod ab omnibus appellatur sacrificium, signum est ueri sacrificii ). ${ }^{17}$ This strategy, however, was not without ambivalence: as Augustine's own argument shows, it could be used to justify ritual sacrifices, such as those of the Jewish cult prior to the coming of Christ and now of the Eucharist, but it could also be cited in support of their discontinuation, 'in order that men might not suppose that the sacrifices themselves, rather than the things symbolized by them, were pleasing to God or acceptable in us'. ${ }^{18}$

At no point, then, in the New Testament or throughout late antiquity were Christians opposed to sacrifice as such. They inherited a world in which traditional forms of sacrifice, as they had been prescribed in the Pentateuch and were similarly practised across the Mediterranean, were declining, and Christianity's ascent to the official religion of the Roman Empire doubtlessly precipitated this decline. Their theological response, prepared in the prophetic books of the Old Testament and in Hellenistic Judaism, was a theory affirming sacrifice at a psychological, volitional, and motivational level, as an attitude of devotion to God, which could but did not have to find expression in ritual form.

\section{From Post-Reformation Controversies to the Modern Affirmation of Self-}

\section{Sacrifice}

Augustine's theory of sacrifice remained unchallenged for the next twelve hundred years. From the sixteenth century, however, the problem of sacrifice became once again burning, and the ambiguities of the Patristic theory permitted starkly divergent responses to the question of its lasting significance in Christianity. More importantly for the present purpose, however, the alternative between the Protestant claim that the death of Jesus was the last and perfect sacrifice and the Catholic affirmation of the truly sacrificial character of the Mass redirected attention to the question of what sacrifice was. In search

(p.18) for an answer, both Catholic and Protestant authors turned to the death of Christ: for the first time, the crucifixion of Jesus truly became the paradigm for sacrificial theory. The Augustinian view therefore, in which this was evidently not the case, satisfied neither side: Protestants sought to affirm that there was a categorical difference between the earlier sacrifices that were required to propitiate God's wrath until the Christ event and everything that happened since. Christian acts of prayer and worship therefore, including the Eucharist, could be called sacrifices in the Augustinian sense as long as it was clear that their affirmation did not mitigate the unique importance of the Christ event. ${ }^{19}$ Catholics, on the other hand, were insistent that in continuity with the Christ event, the Eucharist constituted the Church's only proper sacrifice and was not 
to be confused with the many acts of mercy, worship, and even martyrdom that could, more broadly, be designated by that term. ${ }^{20}$

The problem with making the crucifixion the paradigmatic sacrifice was that, prima facie, it was not at all evident that the events surrounding the death of Jesus could be understood as a sacrifice. The saviour may well be the victima, but who is the sacrificer: the Roman procurator? The mob? The Jewish authorities? None of these seem to qualify; as Thomas Aquinas put it: 'whoever offers sacrifice performs some sacred rite, as the very word "sacrifice" shows. But those men who slew Christ did not perform any sacred act, but rather wrought a great wrong. ${ }^{\prime 21}$

The most influential attempt to cope with this difficulty is given in the biblical Book of Hebrews already: in his sacrificial death, Christ was both victim and priest. In fact the text refers to Christ as the high priest who once a year entered the Holy of Holies to make a sacrifice to atone for the 'sins committed unintentionally by his people' (Heb. 9:7). Jesus of course did not have to atone for his own sins (as the author of Hebrews doesn't fail to point out) -and clearly the point (elsewhere in the New Testament) of comparing him to the victim (for example, the paschal lamb) was to emphasize his purity and innocence. Thus the idea emerges that he acts here in a dual role-as sacrificer and as victim. While outwardly he is subject to an act of violence, he is also, perhaps primarily, actively bringing this event about as the mediator between humanity and God.

Early Protestantism, both Lutheran and Calvinist, developed this idea into the theory of Christ's 'priestly office' (munus sacerdotale ) which is, together with his offices as prophet and king, one of the three works he accomplished during and through his Incarnation. Christ as the God-man reconciles the world to God through his obedience in accepting, on behalf of all (p.19) humanity, the punishment the latter would have incurred by trespassing God's commandment: ${ }^{22}$

Christ through his passive obedience took upon himself the sins of the whole world and atoned voluntarily for the punishments human beings owed by spilling his most precious blood and suffering the most ignoble death on behalf of all sinners so that sins will not be imputed to those who believe in Christ as their saviour for eternal punishment. ${ }^{23}$

Christ's sacrifice is interpreted then in terms of obedience. He willingly suffers the consequences of God's wrath that otherwise would have been directed against humanity in general. He is sacrificed, but the notion of 'obedience' suggests that his role is not like that of other victims. Rather, he accepts this role for himself; indeed he offers himself up to propitiate the wrath of God for the sake of his fellow humans. 
We can easily see why this particular concept seemed attractive to the early Protestants. It aligned the death of Christ with atoning sacrifices of the old covenant. By insisting on the propitiatory character of his Passion, they could set this sacrifice apart from the offerings of thanksgiving Christians were still asked to bring in a variety of ways. ${ }^{24}$ Yet the theory of Christ's priestly office also transformed and modified the idea of sacrifice as ritual. While in the ideal and perfect sacrifice the victima is killed to restore communion with God, he is not merely slaughtered. In fact the historical details of his killing are in an important sense irrelevant for its interpretation. Whether his death was ultimately due to a fanatical mob or to the political machinations of his enemies, their part in this event could not have made Christ's death sacrificial. Rather, it is his own acceptance of this outcome that gives the event its significance. He is the priest bringing the sacrifice; he offers something, his own life, to God. He is both offering and being offered-this is the tantalizing thought we are asked to accept. As required by the logic of the crucifixion, this theory collapses the sacrificial ritual into a single event and reduces the number of persons involved effectively to one, even though this one individual, admittedly, is the God-man.

It must not be ignored that the overt purpose of the Protestant theory, in contrast to its contemporary Catholic rival, was to make sacrifice practically irrelevant for contemporary believers. Its conceptualization was designed (p. 20) to make plausible its absence from true Christianity. There is no doubt that to some extent this was successful: during the first two centuries after the Reformation, sacrificial language is largely absent from Lutheran and Calvinist devotional texts. Two doctrinal transformations happening during the eighteenth century, however, changed this and turned the idea of Christ's obedient selfsacrifice into a popular, universally applicable concept.

The first of those changes concerned the notion of God's wrath; this was increasingly criticized and ultimately rejected by many. By the mid-nineteenth century, the Protestant mainstream had been swayed by the argument that a God who is said to be 'love' cannot at the same time be wrathful. ${ }^{25}$ Yet the traditional idea of Christ's atoning sacrifice was completely bound up with the notion of God's wrath. His death was meant to be a propitiating sacrifice. Once such propitiation became unnecessary or problematic all that remained of Christ's obedience was the notion that he lovingly and humbly fulfilled his earthly ministry patiently accepting his own suffering and death as its culmination. This indeed is the transformed version of Protestant soteriology one finds in nineteenth-century theologians, such as the German Lutheran, Albrecht Ritschl, ${ }^{26}$ and the American Congregationalist, Horace Bushnell.

Ritschl believed that the death of Jesus was necessary for himself and for his followers because only by accepting it he could offer final proof for the principles he had represented in his life. ${ }^{27}$ Ritschl still framed his interpretation in traditional sacrificial language and appealed to the priestly office and to 
Christ's obedience, which for him, characteristically, became an obedience of vocation. ${ }^{28}$ Christ did not have to propitiate God's wrath (a notion Ritschl strongly rejected), but reintroduced human beings into community with God through the ethical and spiritual practice of the Kingdom of God. Such a practice is, according to him, tantamount to a triumph of spirit over nature, and it is for this reason that it needs submission to death as its seal of confirmation. James Richmond explains this as follows:

The positive meaning of the death of Christ is that it is the glorious outcome of his life-long dedication to his vocation-he willingly accepts as the dispensation of God his death at the hands of violent adversaries 'as the highest proof of faithfulness to his vocation. ${ }^{29}$

(p.21) Bushnell, on the other hand, sought to replace the notion of propitiation by expiation. Out of his love for us, Christ: '[...] in what is called his vicarious sacrifice, simply engages, at the expense of great suffering and even of death itself, to bring us out of our sins and so out of their penalties. ${ }^{30}$ Bushnell's preferred analogies for this vicarious sacrifice are motherhood and patriotism:

The patriot or citizen who truly loves his country, [...] how does it wrench his feeling [...] when that country, so dear to him, is torn by faction, and the fate of its laws and liberties is thrown upon the chance of an armed rebellion [Bushnell writes this in 1866!]. Then you will see how many thousands of citizens, who never knew before what sacrifices it was in their power to make for their country's welfare, rushing to the field and throwing their bodies and dear lives on the battle's edge to save it. ${ }^{31}$

Christ's sacrifice here is the outpouring of God's perfect love for his creature whose suffering and agony calls him forth to action on their behalf. All love, according to Bushnell, is sacrificial because it entwines the lover with those he loves, and God's love is supremely so.

While Bushnell's idea of sacrificial obedience is much more active than Ritschl's, both agree on an understanding of sacrifice as self-sacrifice. The identity of priest and victim in Christ has here been fully merged into the notion that his willingness to give something up for the sake of others in itself becomes emblematic of sacrifice. Insofar as Christ's death expresses such an attitude, it can be called sacrificial.

The full impact of this transformation of the notion of sacrifice, however, only becomes evident once it is seen in conjunction with a second development. A fundamental pillar of Protestant orthodoxy was the tenet that the death of Christ was the final sacrifice. What did this finality mean for the religious practice of his followers? In one sense, certainly, they were expected to emulate him, but were they allowed to interpret their own actions in sacrificial terms? The Reformers and subsequent orthodoxy tended to argue that the death of Christ 
was something Christians looked back to and recognized as the token of their salvation. It did not have exemplary significance for their own lives; ${ }^{32}$ they should not think of sacrificing themselves the way Jesus had done.

A major transformation in this regard, however, took place in the late seventeenth and the early eighteenth century. This change can be well observed, for example, in Bach's Passion Oratorios. Where he uses traditional texts from the sixteenth and seventeenth centuries, in the chorals, their reflection on the passion strongly emphasizes the difference between the situation of the (p.22) believer and that of the saviour. He suffers for their salvation; it is this asymmetry believers are asked to appreciate:

I am the one, I should atone:

bound, hand and foot,

in hell.

The scourges and the bonds and what you have enduredmy soul has merited that. ${ }^{33}$

Yet the contemporary, eighteenth-century texts underlying the arias reflect on the passion narrative on the basis of sympathy and identification. The believers find in the passion narrative a paradigm for their own Christian existence:

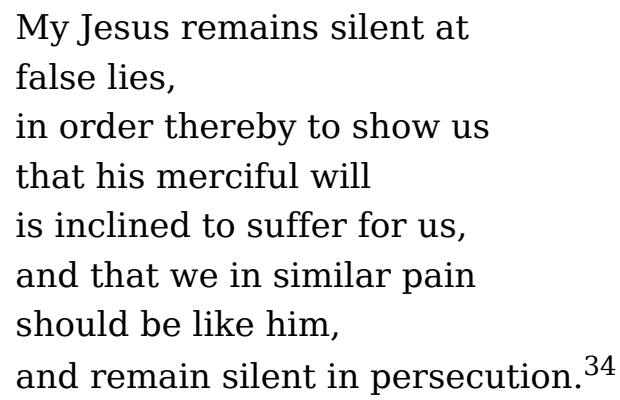

This way of seeing the suffering of Christ in parallel with the afflictions encountered by the believers during their lives is taken for granted in Ritschl's interpretation of the death of Christ. To quote again from Richmond's study: 'When we are struck or slandered [...] Christ's call to us is to share in his patience so that we may lift ourselves above our misfortunes and the world which administers them. ${ }^{35}$

Bushnell, likewise, draws a direct parallel between the sacrifice of Christ and the 'universal' practice of vicarious sacrifice associated with love:

[The vicarious sacrifice of Christ] only does and suffers, and comes into substitution for, just what any and all love will, according to its degree. [...] Nothing is wanting to resolve the vicarious sacrifice of Jesus, but the commonly known, always familiar principle of love, accepted as the fundamental law of duty, even by mankind. Given the universality of love, 
the universality of sacrifice is given also. Here is the deepest spot of good, or goodness, conceivable. ${ }^{36}$

(p.23) It is fascinating to note at this point the extraordinary rapprochement in the nineteenth century between these Protestant and contemporary Catholic views on self-sacrifice. Sixteenth-century theologians, such as Robert Bellarmine, had sought to protect the unique nature of the Eucharist as the Church's only proper sacrifice, in continuation of Christ's atoning death, by means of a strongly ritualistic definition:

Sacrifice is an external oblation made only to God in which, for the strengthening of human infirmity and the proclamation of God's majesty, a material and durable object is consecrated by a legitimate minister in a religious rite and transformed so that it is fully destroyed. ${ }^{37}$

Already in the late seventeenth century, however, this strong ritualism gave way to a more ethical and spiritual interpretation of sacrifice. ${ }^{38}$ The French School of Spirituality (Bérulle, Condren) integrated Bellarmine's theory into an overall Augustinian framework: sacrifice for these writers was primarily internal and spiritual but at the same time aimed at the destruction of the victim:

Sacrifice [...] requires the consumption and total destruction of the object [sc. the victim], and if sacrifices are not consummated through the destruction of hosts and victims, this is because of the imperfection of the human cult and the impotence of the human person who is not capable of more. Thus [the victim's] death is merely a representation of that total destruction of the object which ought to have happened in the sacrifice. ${ }^{39}$

Charles de Condren's work, from which this quotation is taken, unequivocally applies Christ's sacrifice to the spiritual 'annihilation' of the individual Christian and thus contributes to the proliferation of the ideal of self-sacrifice. By the nineteenth century, this line of thought had produced ideas almost indistinguishable from those advanced by the time's liberal Protestants: Christians are asked to emulate Christ's 'infinite obedience', ${ }^{40}$ and while this obedience is still called 'self-annihilation', 41 this self-abnegation is now couched in terms of altruism and duty towards the common good:

From the spirit of sacrifice and from it alone true society is born: it makes subjects as much as it makes kings. To be obedient is not difficult for those who have heard and appreciated this word: 'If any want to become my followers, let them deny themselves and take up their cross daily and follow me' (Luke 9:23). Renouncing oneself in this way, one henceforth lives only and entirely a life of dedication, following the example of Jesus Christ. $^{42}$ 
(p.24) It is at this point that we can perceive in one, important strand of contemporary, secular discourse about sacrifice the result of theological developments, a convergence of streams that had parted in early modernity but continued to be fed by the same biblical and Patristic tributaries. Sacrifice as an expression of selfless commitment to the good of the community is the endresult of a trajectory that previously saw the transformation of the idea that the death of Jesus was a propitiating sacrifice offered by himself into the notion of Christ's sacrificing his own life through active love, self-demotion, and patient suffering on behalf of his friends. This self-sacrifice is, further, understood ethically to express the example and the ideal of Christian existence.

This could be applied to more extraordinary situations-we have seen Bushnell refer to war and analogous uses were extremely popular during the First World War. Yet overall more typical is its appropriation to the ideal of civic vocation in what Charles Taylor has called the 'affirmation of ordinary life'. ${ }^{43}$ This willingness to 'sacrifice' by giving up for the benefit of others and in the interest of one's community continues to loom large in contemporary discourse on sacrifice.

3. Sacrifice and the perspective of the victim

The identification of sacrifice as self-sacrifice, while becoming dominant only in the eighteenth century, goes back to Augustine. By contrast, the association of sacrifice with an act of violence committed to an innocent victim seems a genuine product of European modernity. While recent discussions of sacrifice invite the implication that this link was perceived for a long time, historical evidence suggests otherwise: in modern European languages, the emergence of a generic use of 'victim' and its derivatives for objects of acts of violence, injustice, or abuse is a secondary phenomenon clearly derived from Christological discussions. It is not aligned to debates about sacrifice until the eighteenth century. ${ }^{44}$

This is not to deny that the particular cruelty and the human suffering at the heart of the Christian atonement were noted much earlier. Yet it seems to have been, originally, the external more than the internal perception of Christianity which focused on this aspect. From the Platonic philosopher Celsus in the second century onwards, the charge that Christianity glorifies suffering and generally under-achievement has accompanied its history. In (p.25) the late nineteenth century, Friedrich Nietzsche emphatically reiterated this claim. ${ }^{45}$ It would be simplifying things unduly to attribute this perception of Christianity entirely to the notion of Christ as victima, but clearly the founder's death on the cross must have played its role. ${ }^{46}$ By contrast, theological reflections on the death of Christ initially did not emphasize his pain or physical suffering. Nor did other forms of representation: the first crucifix depicting a visibly suffering Christ only dates from the early Middle Ages. ${ }^{47}$ It is part of the devotional revolution during the high Middle Ages that Christ's physical pain, symbolized 
through the spilling of his blood, becomes a dominant feature of Christian perceptions of the cross and its often drastic rendering, a favourite motive of religious art. $^{48}$

Early modern theological developments could not but exacerbate this trend. In the debates about the nature of sacrifice that followed the Reformation, both sides insisted, albeit for different reasons, on the centrality of the immolation of the victim. ${ }^{49}$ For Protestants this underlined the plausibility of their claim that the death of Jesus was the perfect-and final-proper sacrifice. Catholics, on the other hand, sought to prove that only the destruction of the material of the host through transubstantiation guaranteed the validity and efficaciousness of the Eucharist as the genuine continuation of the Christ event. Both lines of argument did not in any obvious way advance cruelty to victims-Protestants held that since the death of Christ sacrifice had become redundant while for Catholics the true sacrifice merely involved the offering of bread and wine. Yet in these discussions the view gained currency that the essential property of sacrifice was the violent destruction of a sentient being, paradigmatically the crucifixion of Jesus Christ.

It was, therefore, in opposition to this particular view that, beginning from the eighteenth century, sacrifice was rejected as the wilful annihilation of life. As Derek Hughes shows in his contribution to the present collection (Chapter 15), antisacrificial attitudes dominated eighteenth-century adaptations of Iphigenia. In Fénelon's Aventures de Télémaque, the idealized inhabitants of Salento are characterized by their refusal to immolate the sacrificial victim: the animals are 'presented' at the altar but not killed. ${ }^{50}$ The same era sees the emergence of the view that the paradigmatic (p.26) sacrificial victim is a human being. ${ }^{51}$ This implication reinforces Voltaire's critique of religion as inherently cruel: no religion without sacrifice, no sacrifice without the immolation of a victim and thus, ultimately, without the killing of human beings. ${ }^{52}$ It is not difficult to recognize behind these three notions theological principles emphatically affirmed by Counter-Reformation thinkers; the critical twist against the continuation of sacrifice, meanwhile, was furnished by arguments culled from their Protestant opponents.

Eighteenth-century rejection of sacrifice, then, was in many ways inspired by opposition to the Christocentric construction of sacrifice as the immolation of a (human) victim in post-Reformation debates. A proper theological 'turn to the victim', on the other hand, did not happen until much later. Finding in Jesus Christ's sacrifice the model for all human suffering in the world really was a theological idea of the twentieth century. After the First World War, Christological and soteriological argument increasingly moved away from the view according to which Christ's sacrificial dying represented a model of heroic acceptance of the consequences of his mission and towards an emphasis on the relevance of suffering in the world as expressed through the centrality of this 
event. ${ }^{53}$ God reveals himself precisely through his abasement-this was already the fundamental idea in Luther's theology of the cross, ${ }^{54}$ and this conviction stands behind many modern interpretations which stress the innocent suffering of the victim.

It is this development that has finally led to the identification of sacrifice with the suffering of innocent victims as it is encountered most famously in René Girard's theory, but which is, in less articulate forms, widely held in contemporary societies. Girard himself has sought to support his view through a wide-ranging theory of culture in which a particular interpretation of Christianity and the biblical writings play a major role. As the present chapter should have demonstrated, history at best offers partial confirmation of Girard's narrative. He is hardly right in identifying every sacrifice with an act of victimization; even within Christianity his theory relies largely on specific developments since the Reformation which emphasized the immolation of the victim and subsequently provoked radical opposition to the very notion of sacrifice. It is, however, arguable that the post-Reformation theories are the (p. 27) result specifically of an attempt to understand sacrifice from the vantage point of the Christ event and thus far Girard's intuition to see in the ensuing critical trajectory a result of the biblical narrative is not far-fetched.

\section{Conclusion}

What has Christianity done to the concept of sacrifice? How has it influenced the ways in which people today, whether or not they are theologians, speak about sacrifice? I started from the observation that Christianity emerged in a historical situation that saw the end of most traditional sacrifices. The Christian response to this, as exemplified by Augustine, was pragmatic and followed largely the example set by Hellenistic Judaism: sacrifice was in principle affirmed but reinterpreted as an internal attitude of religious devotion to God and its manifestation in moral behaviour. Sacrifice thus became self-sacrifice, a sacral transformation of the person which could, but did not have to be, symbolized by an external offering. The case for this re-imagination of sacrifice as self-sacrifice was largely made on the basis of Old Testament texts contrasting empty rituals with true spirituality and morality. In the sixteenth century, by contrast, the debates about sacrifice triggered by the Reformation turned to the death of Christ as the paradigmatic sacrifice and therefore emphasized the violent destruction of the victim as a central component of the sacrificial act. Selfsacrifice now became associated with annihilation, with patient endurance in hardship, and with obedient suffering. While Catholic and Protestant interpretations went radically different ways initially, the two sides eventually settled on similar views endorsing altruistic acts of self-submission for the benefit of the greater good in a spirit that could be, and has been, adapted eagerly by nation states and civic societies ever since. 
At the same time, the Christocentric turn in sacrificial theory during the Reformation period also gave rise to the critical argument that sacrifice was essentially cruel and brutal, the senseless taking of human life. It is from this trajectory that, since the eighteenth century, the usage of victima for any kind of 'victim' became popular in European languages: instances of unjust and cruel human suffering were thus inscribed into a sacrificial logic, they became types of the suffering victima on the cross. There lies some irony, then, in the fact that this universalization of the sacrificial logic went hand in glove with a fundamental rejection of that very logic. As the contribution by Wolfgang Palaver to this volume evidences (Chapter 6), the argument cuts both ways even today: it appears that if sacrificial mechanisms are recognized in all human violence, these mechanisms must be denounced, and sacrifice must be (p.28) rejected. Yet if it is also true that only their identification as instances of victimization transformed acts of violence from unexceptionable parts of human culture into something truly reprehensible, this would indicate that the category of sacrifice is inadmissible for the peaceful future of human society.

In the final instance, it is this paradox that Christianity has bequeathed to the modern world. While it was predicated on 'the end of sacrifice' as it had been known and practised by most cultures for thousands of years, this religion has given to discourse and reflection about sacrifice the most central place imaginable. With only little exaggeration we can say that this is our own situation today still.

It is characteristic that this situation offers the semantic possibility of classifying various practices as sacrifice. This happened in Hellenistic Judaism, then throughout Christian history and continues in secular modernity. While one can hardly decree such interpretations illegitimate or wrong, it seems important to recognize that these debates would not exist if it were not also true that in a rather obvious way sacrifice is absent from society as we know it. There is a sense in which we are unwilling to believe that anything that has existed in human culture would ever totally and utterly leave us. In the case of sacrifice this certainly seems to be the case; whether this is cause for worry or comfort is very much an open question today.

Notes:

(1) Strenski, Theology, 1-2.

(2) Burkert, Homo Necans.

(3) Girard, Violence.

(4) Hubert/Mauss, Sacrifice, 10.

(5) Stroumsa, End of Sacrifice. 
(6) For Julian's attitude to sacrifice cf. Belayche, 'Sacrifice during the "Pagan Reaction"'.

(7) Julian, contra Galilaeos, 306.

(8) Julian, contra Galilaeos, 354 A.

(9) Eusebius, de demonstratione evangelii I 10.

(10) Belayche, 'Sacrifice during the "Pagan Reaction"', 117.

(11) Didache 14, 1-3.

(12) Justin, Dialogus 117.

(13) Justin, Dialogus 117, Ed: Robertson/Donaldson, 257. The traditional attitude is summed up well in Sallustius' de diis et mundo 16, 1: 'Prayers without sacrifices are only words'.

(14) Cf. Mazza, 'The Eucharist in the First Four Centuries', 35-40. Mazza helpfully argues that these parallels illustrate the precise sense in which the early Eucharist was considered a sacrifice, but fails to point out that they also imply a radical discontinuity with traditional ritual sacrifice.

(15) Augustine, de civitate dei X 4-6.

(16) Augustine, de civitate dei X 5.

(17) Augustine, de civitate dei X 5.

(18) Augustine, de civitate dei X 5.

(19) Hollaz, Examen theologicum acroamaticum, 1139.

(20) Bellarmine, de Missa I 2 (p. 477).

(21) Thomas Aquinas, Summa Theologiae III, q. 48, art. 3, obi. 3 (vol. 4, p. 290). The same problem is discussed in Bellarmine, de missa I 3 (p. 478-479).

(22) Lutheran theology at some point distinguished further between active and passive obedience, but this never became generally accepted as it seemed to suggest that Christians themselves had no obligation to follow the divine commandments. Cf. Schmid, Dogmatik, 259-261.

(23) Oboedientia passiva Christus totius mundi peccata in se transtulit et poenas iis debitas ultro luit, sanguinem suum pretiotissimum fundendo et mortem ignominiosissimam pro omnibus peccatoribus obuendo, ut credendibus in 
redemtorem Christum peccata ad aeternam poenam non impunetur (Hollaz, Examen theologicum acroamaticum, 737).

(24) Melanchthon, Apologia XXIV (p. 253); Hollaz, Examen theologicum acroamaticum, 1139.

(25) Cf. Schwager, 'The Theology of the Wrath of God'; Volkmann, Der Zorn Gottes.

(26) On Ritschl, see: Richmond, Ritschl. On the work of Christ esp. ch. 5. For Ritschl's influence on the emergent science of religion cf. Jones, The Secret of the Totem, ch. 2, and the critical assessment of this reading by Strenski, 'Durkheim's Bourgeois Theory of Sacrifice'.

(27) Ritschl, Rechtfertigung und Versöhnung, vol. 2, 41-88, esp. 41-42. Cf. Marsh, Albrecht Ritschl.

(28) Cf. e.g. Ritschl, Unterricht in der christlichen Religion §§ 50-51 (pp. 67-69).

(29) Richmond, Ritschl, 184. The reference is to Ritschl, Justification and Reconciliation, 477.

(30) Bushnell, The Vicarious Sacrifice, 41.

(31) Bushnell, The Vicarious Sacrifice, 46-47.

(32) Cf. Lage, Martin Luther's Christology and Ethics, 98-102.

(33) Marissen, Bach's Oratorios, 35: 'Ich bin's ich sollte büßen, / an Händen und an Füßen / gebunden in der Höll. / Die Geißeln und die Banden, / und was du ausgestanden, / das hat verdienet meine Seel.'

(34) Marissen, Bach's Oratorios, 50: 'Mein Jesus schweigt zu falschen Lügen stille. Um uns damit zu zeigen, dass sein Erbarmens voller Wille vor uns zum Leiden sei geneigt, und dass wir in dergleichen Pein ihm sollen ähnlich sein und in Verfolgung stille schweigen.'

(35) Richmond, Ritschl, 183.

(36) Bushnell, The Vicarious Sacrifice, 48.

(37) Bellarmine, De missa I 2 (p. 477).

(38) Despland, Le recul du sacrifice, 80-85.

(39) Condren, L'idée du sacerdoce, 48.

(40) de Lamennais, Essay de l'Indifference IV 15 (vol. 4, pp. 77, 80-81). 
(41) de Lamennais, Essay de l'Indifference IV 15 (vol. 4, p. 79).

(42) de Lamennais, Essay de l'Indifference IV 15 (vol. 4, p. 83).

(43) Taylor, Sources of the Self, 211-302.

(44) Despland, Le recul du sacrifice, 139-147.

(45) Cf. for Celsus his scathing comments on Christ's death and his later remarks on the attractiveness of Christianity for those who are contemptible: Alethes Logos, fr. II 16-26 and III 44-63 with clear echoes of 1 Cor 1:21ff. For Nietzsche see: Zur Genealogie der Moral I 7 (p. 267).

(46) Nietzsche's 'transvaluation of values' is clearly present in the preaching of Jesus himself, e.g. in his Beatitudes (Mt 5:3-10).

(47) Beutler, Der Älteste Kruzifixus.

(48) Cf. Walker Bynum, Wonderful Blood.

(49) Carraud, 'De la destruction'.

(50) Despland, Le recul du sacrifice, 141-142.

(51) It is interesting that in Thomas Aquinas the fact that in the crucifixion a human being is killed is still cited as an argument against the sacrificial interpretation of Christ's death: 'But human flesh was never offered up in the sacrifices of the Old Law, which were figures of Christ: nay, such sacrifices were reputed as impious' (ST III, q. 48, art. 3, obi. 1 [p. 290]).

(52) Despland, Le recul du sacrifice, 144-145.

(53) Fiddes, The Creative Suffering of God, and his contribution to this volume.

(54) Cf. his Heidelberg Disputation Theses 19-21: 'Non ille digne Theologus dicitur, quit "invisibilia" Dei "per ea, quae facta sunt, intellecta conspicit", sed qui visibilia et posteriora Dei per passiones et crucem conspecta intelligit. Theologus gloriae dicit malum bonum et bonum malum. Theologus crucis dicit id quod res est (Werke in Auswahl, vol. 5, p. 379).

\section{Access brought to you by:}

